\title{
THE MAIN DETERMINANTS OF DEVELOPMENT -PLS PATH ANALYSIS APPLIED TO THE FACTORS OF ENDOGENOUS DEVELOPMENT
}

\author{
Gábor BODNÁR* \\ University of Szeged, Hungary
}

\begin{abstract}
Many empirical analyses have been based on the theory of endogenous development, referring to the utilisation of given resources and providing the framework of quantitative analysis. The concept can be especially important in the case of less favoured and/or rural areas. However, the empirical analyses of this widely used theory often neglect the countryside or lay minimal focus on them. The research project presented here investigates the key factors of endogenous development and their presence in the rural districts of Hungary. The main aim of the paper is the examination and explanation of the effects of each capital on development. The study provides a review of the academic literature of development theories, as well as the understanding and development of the concept over the last few decades. The paper briefly addresses the delimitation of the Hungarian countryside, and it also proposes a regression model for the explanation of development, including latent variables symbolising the forms of capital. The model is examined by applying partial least squares (PLS) path analysis, which shows the connections between each form of capital through a dynamic approach. The analysis conducted for the years of 2009, 2013 and 2017 indicates that the relationship between the capitals is defined by temporal differences. Similar interactions can be seen between the capitals in 2009 and 2013, but 2017 shows a completely different system of relations. Hence, the findings show that, in a rural context, the relations between the forms of capital vary considerably over time.
\end{abstract}

Keywords: rural districts of Hungary, endogenous development, PLS Path Analysis

JEL classification: C31, O18, R11

\footnotetext{
* Corresponding author. Address: University of Szeged, Faculty of Economics and Business Administration, H-6722 Szeged, Kálvária sgt. 1, Hungary, Tel. +36-30/209-2276, Email bodnar.gabor@eco.u-szeged.hu
} 


\section{Introduction - The "evolution" of development theories}

Current research findings clearly show that the economic development of Eastern and Central European regions has recently shifted from the dominance of exogenous elements in an endogenous direction, i.e., an increasing number of local factors ("soft endogenous factors", such as human capital and informal knowledge) define the competitive advantages of regions (Capello \& Perucca 2013; Smętkowski 2018). Economic development also includes the role of regional institutions as a significant element, the quality of which evidently contributes to the advancement or decline of a region (EC 2017). Following a short review of development theories, the elements of endogenous regional development are examined, presenting some special approaches of endogenous development.

"The concept of development, in the most general terms, refers to the process which leads to a lower level of quality to the higher level of quality" (Szentes 2011, 13). In this context, Szentes (2011) describes that the concept of development has been interpreted in various ways over the past centuries, especially recently, depending on the discipline of social science. The issue of different interpretations is also mentioned by Todaro and Smith (2009), adding that without a certain degree of general agreement, it is not possible to take measurements and to basically define which country is developing and which one is not. The Authors (2009) also claim that in strictly economic terms, the concept traditionally referred to achieving a long-term increase in income per capita which enables an increase in national output at a faster rate compared to the growth of population. Development was in fact defined in the same way much earlier by Lord Robbins (1968), which is in line with this narrower economic approach.

At the same time, Sen (1988) "goes even further", integrating humanum into his approach, based on which he establishes that the improvement of living conditions should clearly be one of the most important, if not the most important, tasks of economics and this, earlier mentioned "improvement" process is an evident part of the concept of development (Sen 1988). Development thus needs to be understood as, for instance, a multi-faceted process involving the significant changes of social structures and national institutions, which includes the stimulation of economic growth, reduction of inequalities and putting an end to poverty (Todaro and Smith, 2009) ${ }^{1}$.

Regarding the interpretation of the theory of development, Lewis (1988) uses the term 'growth', still, his view includes the qualitative character of change. More specifically, the Author (1988) interprets development theory as '...those parts of economics that play crucial roles when one tries to analyze the growth of the economy as a whole' (Lewis 1988, p. 36).

Or, as Chant and Mcllvaine (2009) describe, development theory is concerned with change much more than it is expected in conventional social sciences. Development theory has always had a close link with the development strategies which intended to put theory into practice. The emergence of the theory was linked to the world after 1945, with its changing financial possibilities in the relationship between the developed and the developing world.

\footnotetext{
${ }^{1}$ As it is also emphasised by Lengyel (2012a), Amartya Sen's ideas are apparent in the authors' approach.
} 
Distinguishing the major trends of the recent decades, the following categorisation is possible (Chant and Mcllvaine 2009; Lengyel 2012a):

- modernisation theories, mostly prominent in the 1940s and 1950s but remaining relevant until the 1960s;

- dependency theories, significant in the 1960s and 1970s;

- neoliberal and structural change theories, emerging in the 1980s and continuing in the 1990s and 2000s;

- post-development theories, during the 1990 s and 2000s.

Hoff and Stiglitz (2001) also indicate the middle of the $20^{\text {th }}$ century as a point of time since when marked changes have taken place in terms of understanding development. As the Authors (2001) put it, we know that development is possible but not inevitable and there is no recipe for success.

Related to this review, Szentes (2011) points out that economics has been concerned with the question of development since the establishment of modern social-economic systems. The Author (2011) adds that the theoretical historical ${ }^{2}$ review of economics can reveal several theoretical, economic, and political questions which, as described above, are also featured in development economics emerging independently after the Second World War.

In agreement with this approach of the discipline, and, at the same time, referring back to the different approaches of development theory, Sen's (1988, p. 23) opinion can be called apt and practical, concluding that "...work on development economics need not await a complete 'solution' of the concept of development".

When investigating territorial aspects of development of any kind, the aim must be the creation or emergence of a successful region. Regarding the concept of success and a successful region, György Enyedi's (1998, 409-411.) idea of success is indicative; besides formulating the criteria of competitiveness, it pays attention to environmental sustainability and the aspects of social justice: „...in a successful region, produced income increases. A significant part of this income is used locally for investments, entrepreneurial and personal income, as well as settlement management and development in the form of taxes. Broad sections of the population have a share in the income growth, economic growth does not harm either the natural environment or the built and cultural values of the region. Finally, the growth affects all settlement groups of the region and it does not increase the territorial inequalities within the region".

Among the spatiality-related trends of development, whether it is location theory or regional growth and development theory, in general two important tendencies have gained ground in the past ten-twenty years (Capello 2012, p. 315):

- 'a tendency to achieve more realism in sometimes abstract conceptual approaches;

- a tendency to develop a dynamic perspective'.

The concept of development can be interpreted in its narrower economic context. As regards the latter, Capello and Nijkamp (2011) includes societal

${ }^{2}$ Lewis (1988) offers an excellent historical review, examining the theory of development from the dawn of economics. 
opportunities, healthy environment, and high-standard education as examples. However, as Stimson et al., (2011) refer to regional and economic development in relation to development, they distinguish attributes measurable by quantitative and qualitative tools. Even though the levels of wealth and income or job creation are essential, creative capital, the low level of social and economic differences or sustainable development are of the same importance.

\section{Theoretical Background - A modern interpretation of endogenous development}

The endogenous variety of development can be regarded as its revaluated theory. If we examine the term itself, „...endogenous in economics refers to factors which are not hereditary ("are not from God") but are created consciously through economic activities. In regional studies, we consider community developments and actions which are consciously created, based on unique local factors, bottom-up and actively involving the local society within a region to have an endogenous character" (Lengyel 2012b, 145).

The emergence of endogenous development itself is traced back to the end of the 1980s by Benko (1997), although he referred to industrial and city regions, while Vázquez-Barquero and Rodríguez-Cohard (2016) date its gaining significance at the early 80 s.

Similarly, Amin (1999), in his article from two decades ago, establishes that the European regional policy was defined by the Keynesian heritage in the case of developed countries from the 60s to the then recent past. This approach relied on the redistribution of income and the demand stimulating effects of welfare policies in the case of less developed regions. In their case, the Keynesian regional policy undoubtedly increased employment and incomes, but these territorial units could not maintain the achieved results permanently and could not manage to realise "self-sustaining" growth based on their own resources. Thus, according to the Author (1999), after the failures of the Keynesian and the pro-market, neoliberal policies, the focus on the theory of endogenous development can be interpreted as a sort of third-track approach. In line with this, Tödtling (2009) considers the theory of endogenous regional development as a kind of "counter-theory", which responds to the former development concepts that emphasised the importance of external factors in the case of less developed regions, such as interregional trade or the mobility of capital, work, and technology.

Consequently, in the past few decades there has been a shift in the emphasis and focus of regional development theory from exogenous factors to endogenous elements (Stimson et al. 2011), the prevalence of which is also described by Lengyel (2012a).

It can be established that the whole theory relies on the assumption that the basic preconditions of development, sense of initiative and enterprises, are available or present in a latent way in most regions (Tödtling 2009). Similarly, according to Capello's $(2007,2011)$ views, endogenous development basically depends on the concentrated arrangement of a region, it is an integral part of a social-economic and cultural system, whose components determine the success of local economy: entrepreneurship, factors of local production (work and capital), and the relationship management skills of local actors, which increasingly contribute to the increase of knowledge creation. 
According to Capello's (2007) approach, the main reason of regional differences is the uneven distribution of innovative activities. It can be observed that while today work and capital move very easily, the least mobile factors are precisely those immaterial factors which are, among others, related to innovative capacity.

When Stimson et al. (2011) refer to regional and economic development in the context of development, they distinguish attributes measurable with quantitative and qualitative tools. In another work, Stimson et al. (2009) make regional economic development subject to the strength or weakness of the quality of the (local) management, the efficiency of institutions and the level of the significance of enterprises. These dynamic relationships shape the characteristics of development and the performance of a region. It can be observed that institutions, entrepreneurship, and the quality of (local) management are the three most crucial factors, not only in terms of shaping the performance of the region but they can also substantially improve a region's capacity and conditions (Stimson et al. 2009).

Although the present paper primarily focuses on the endogenous variety of development, certain exogenous elements cannot be ignored even under the current circumstances. Stimson et al. (2009) suggest the internationalisation of financial processes and the movement of labour between regions are typical examples. Related to their above-described new framework, the Authors (2009) claim that it is crucial for a region that the institution system and the (local) management are able to and manage to acquire exogenous factors which are necessary to provide the incomplete endogenous conditions and generate new competences and conditions. Tödtling (2009) also suggests that regional development is always the collective result of endogenous and exogenous factors, thus there are several paths of development, and there is no ideal solution.

As Lengyel (2012a) establishes, today endogenous trends have gained focus in the field of regional growth and broadly defined development. It is linked to the fact that the various trends include ones which base the system of endogenous elements on the concept of capital (Lengyel 2012a). Thus, besides economic capital, several new forms of capital have gained focus.

Following a similar logic, as a part of the recent evolution of economic thinking, Stimson et al., (2011) write that in the past two decades, a further move has been made in terms of integrating the directives of sustainable development in the area of regional development and planning.

Table 1 Appearance of each form of capitals in various endogenous development models

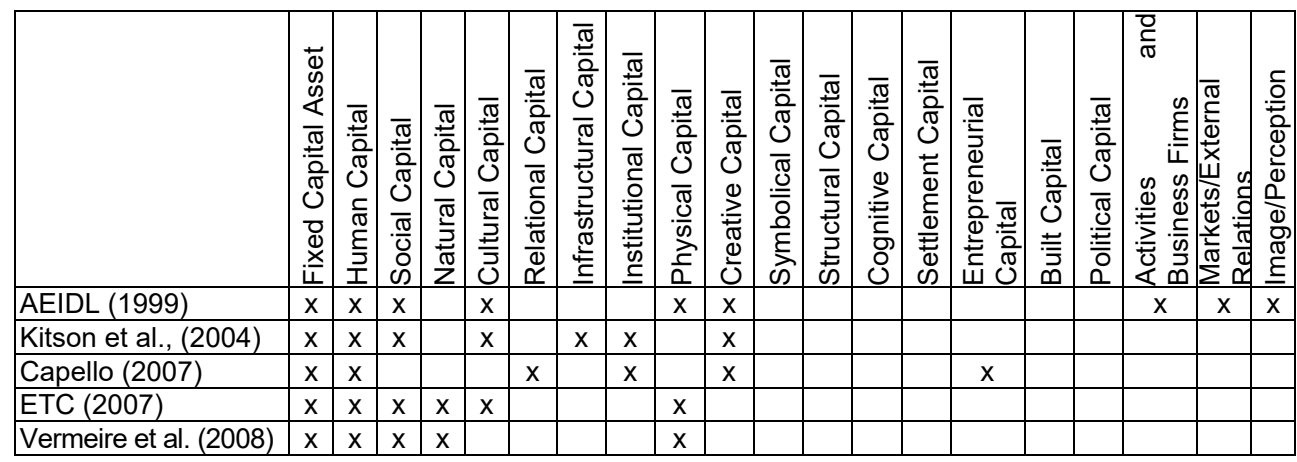




\begin{tabular}{|c|c|c|c|c|c|c|c|c|c|c|c|c|c|c|c|c|c|c|c|c|}
\hline & 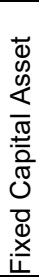 & 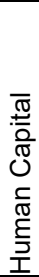 & 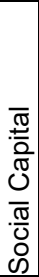 & 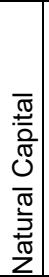 & 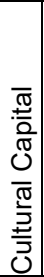 & 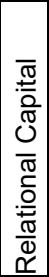 & 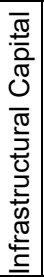 & 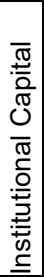 & 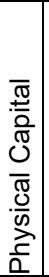 & 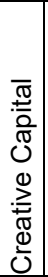 & 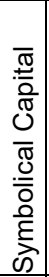 & 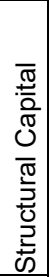 & 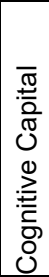 & 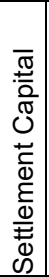 & 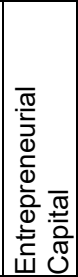 & 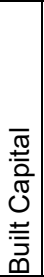 & 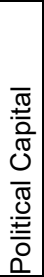 & 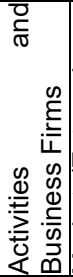 & 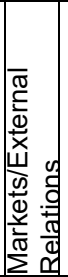 & 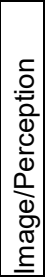 \\
\hline Camagni (2008) & $x$ & $x$ & $x$ & $x$ & $x$ & $x$ & $x$ & $x$ & & & & & & & & & & & & \\
\hline Braithwaite (2009) & $x$ & $x$ & $x$ & $x$ & $x$ & & & & & & & & & & & $x$ & $x$ & & & \\
\hline $\begin{array}{l}\text { Affuso and Camagni } \\
(2010)\end{array}$ & & & $x$ & & $x$ & $x$ & $x$ & & & & & & $x$ & & & & & & & \\
\hline Milone et al. (2010) & $x$ & $x$ & $x$ & $x$ & $x$ & & & $\mathrm{x}$ & & & $\mathrm{x}$ & & & & & & & & & \\
\hline Stimson et al. (2011) & $x$ & $x$ & $x$ & $x$ & & & & & & $x$ & & & & & & & & & & \\
\hline Brasili et al. (2012) & $x$ & $x$ & $x$ & $x$ & & $x$ & $x$ & & & & & & $\mathrm{x}$ & $\mathrm{x}$ & & & & & & \\
\hline $\begin{array}{l}\text { Lengyel and Szakáné } \\
\text { Kanó (2012) }\end{array}$ & $x$ & $x$ & $x$ & & & $x$ & $x$ & $x$ & $x$ & & & & & & & & & & & \\
\hline Atkinson (2013) & $x$ & $x$ & $x$ & $x$ & $x$ & & $x$ & $\mathrm{x}$ & & & & & & & & $x$ & & & & \\
\hline Dinya (2013) & $x$ & $\mathrm{x}$ & $x$ & $\mathrm{x}$ & $\mathrm{x}$ & $x$ & $\mathrm{x}$ & $x$ & $x$ & & & & & & & & & & & \\
\hline Tóth (2013) & $x$ & & $x$ & $x$ & $x$ & $x$ & & & & & $\mathrm{x}$ & $x$ & & & & & & & & \\
\hline Rechnitzer (2016) & $x$ & $x$ & $x$ & & $x$ & $x$ & & $x$ & & $x$ & & & $x$ & & & & & & & \\
\hline
\end{tabular}

Source: own construction based on Tóth $(2013,44$.)

For developing the indicator system used in the empirical analysis, it is summarised which (capital) factors are mentioned primarily in the academic literature of the topic (Table 1).

Based on their frequency in Table 1, seven forms of capital have been included in the model: private fixed capital, human capital, social capital, cultural capital, relational capital, infrastructural capital, and natural capital.

At the same time, some statistical and methodological challenges arose during the analysis:

- Private fixed capital, which refers to the development of economy and can be approached from several sides (e.g. Brasili et al. 2012; Camagni, et al. 2011), has been divided into two parts: private fixed capital, representing the target variable of the model, signifies individual wealth, while entrepreneurial milieu involves the indicators to express prosperous business environment.

- It must be noted that due to its relevancy, natural capital was intended to be included in the analysis. However, as it could not be described quantitatively, this form of capital had to be excluded.

Ultimately, the following capitals (latent variables) form the model: the target variable is called private fixed capital, and the independent (latent) variables are cultural capital, entrepreneurial milieu, human capital, infrastructural capital, relational capital, and social capital.

To quantify the selected capitals, the Hungarian database $\mathrm{TelR}^{3}$ was used and, finally, 33 pieces of indicator were involved in the analysis. (15 of them describe

3 "The National Regional Development and Spatial Planning Information System (in Hungarian: TeIR) makes statistical data of different data owners available in one system, supporting planning and evaluation activities from the national to the local level." - http://uj.lechnerkozpont.hu/en/oldal/teir 
the material capitals and 18 embody the immaterial ones.) The indicators of each capital can be seen in Annex I.

Furthermore, it was attempted to represent not only the relations between the latent variables, but also the dynamics of connections. Hence, the same model was built for 2009, 2013 and 2017. The time difference makes it possible to analyze the change of relationships as well (Figure 1).

Figure 1 Framework of the analysis

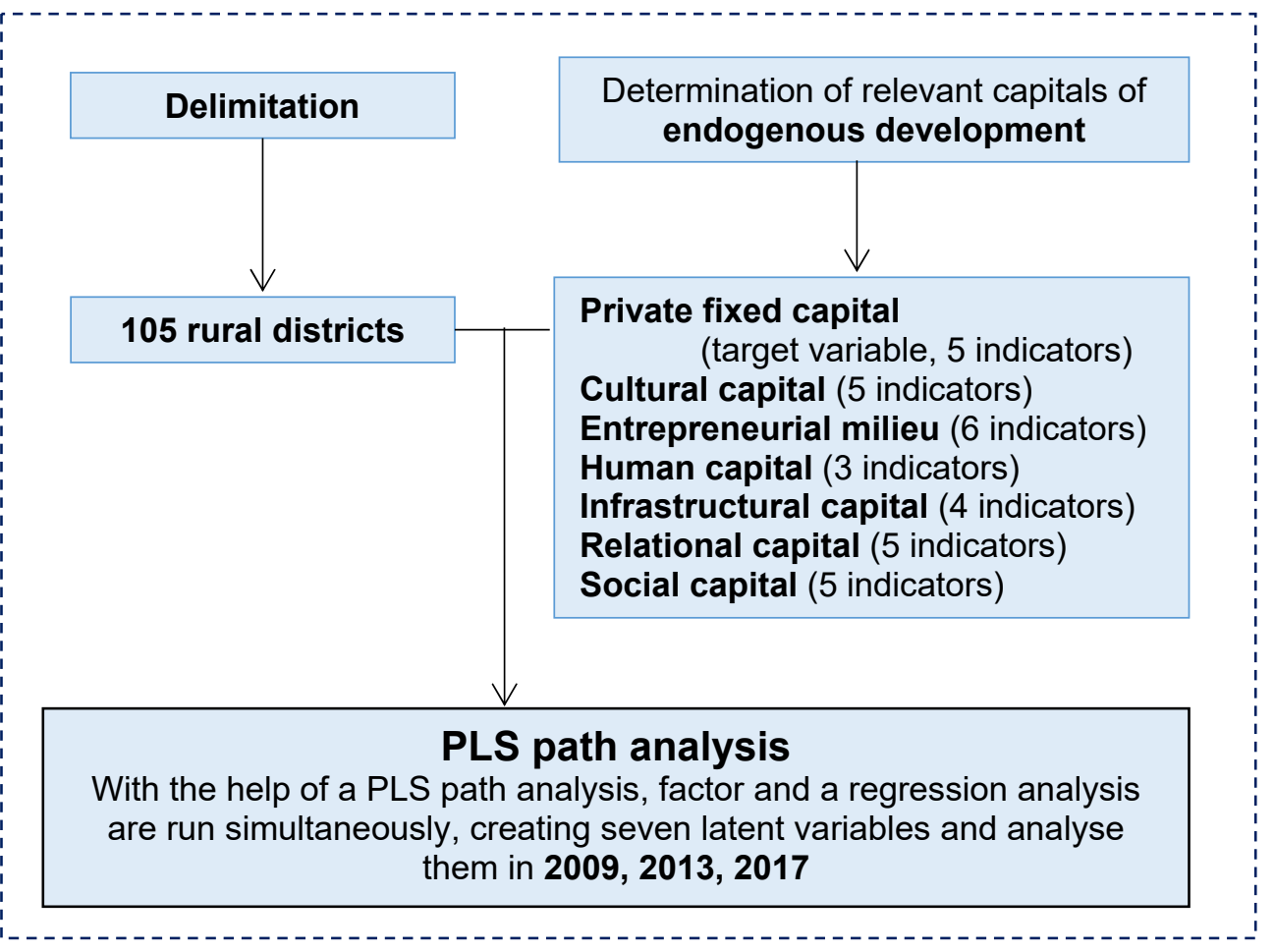

\section{Delimitation}

There are several approaches for the territorial interpretation of the Hungarian countryside ${ }^{4}$. This paper does not aim to provide a detailed review of the topic. Furthermore, due to the complexity of the issue, there is probably no single best solution which could be applicable at all territorial levels, thus it is not intended to address this issue. In this part of the paper, it was sought to choose the most suitable territorial level from the aspect of quantifying the development of the Hungarian countryside.

Realising and knowing the limitations of the system, the nomenclature of districts was still selected as a basis for the research, considering its advantages related to data analysis.

\footnotetext{
${ }^{4}$ See Bodnár (2011)
} 
Based on this, a threshold of 120 persons $/ \mathrm{km}^{2}$ was applied as the framework of the analysis, as suggested by Csatári (2001), among others. Adjusting to the Hungarian system of settlements, in total 105 districts were delimited as a rural territorial unit.

\section{Figure 2 Rural districts of Hungary}

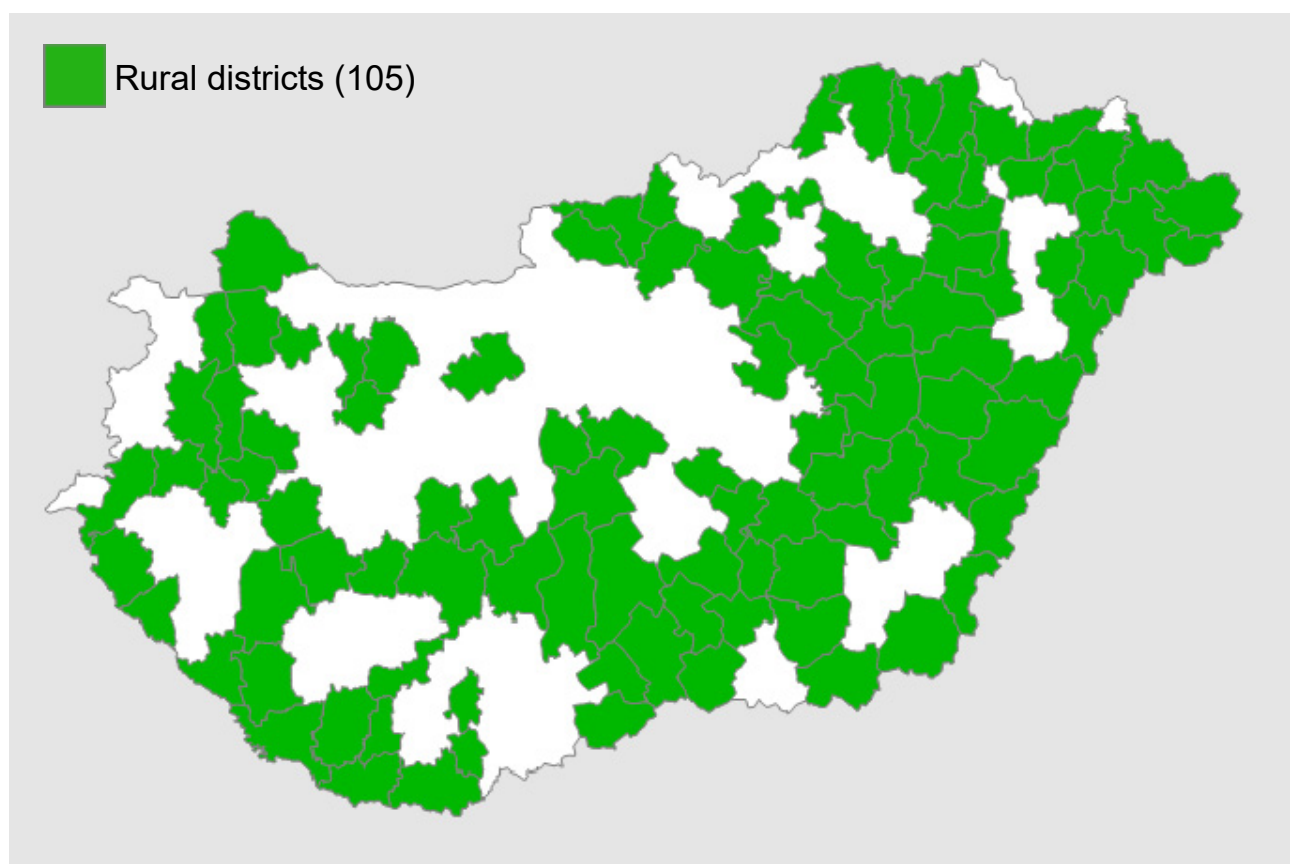

Although the degree of the "rural character" of each district is different, the data on the delimited Hungarian rural regions regarding 2018 are the following:

- their area is $57,175 \mathrm{~km}^{2}$ in total, which is $61 \%$ of the area of the country;

- their population is $3,015,799$ people, which is $31 \%$ of the population of Hungary.

Besides the above-described attributes, the districts presented in Figure 2 are also characterised by a decreasing and ageing population, to a varying extent. Agriculture is still a relatively dominant sector. In addition, the level of unemployment can be considered high in all age groups, although its rate can be different, moreover, the average level of educational attainment is low. At the same time, it is also to be noted that these phenomena are not exclusively associated with Hungarian processes, of course. Pociūtè-Sereikienè et al. (2014) also wrote about the intensification of polarisation among the post-socialist countries of the European Union, particularly between large cities and economic hinterlands. Also, Egri and Tánczos (2015) write about a very similar spatial structure regarding Central and Eastern Europe in their work. 


\section{PLS path analysis - original model}

PLS path analysis was applied to examine the relationships between the latent factors, which were conducted with SmartPLS 3 software. With the method of PLS path analysis and using the developed latent variables, it was aimed to apply a regression model that is able to explain which factors affect the existing welfare ${ }^{5}$ among the Hungarian rural districts and to what extent, which is interpreted as the synonym of private fixed capital in a simplified way. The advantages of the methodology are also addressed by Tubadji and Nijkamp (2015), as well as Kovács and Bodnár (2017).

Figure 3 Relationship of factors explaining private fixed capital - original model

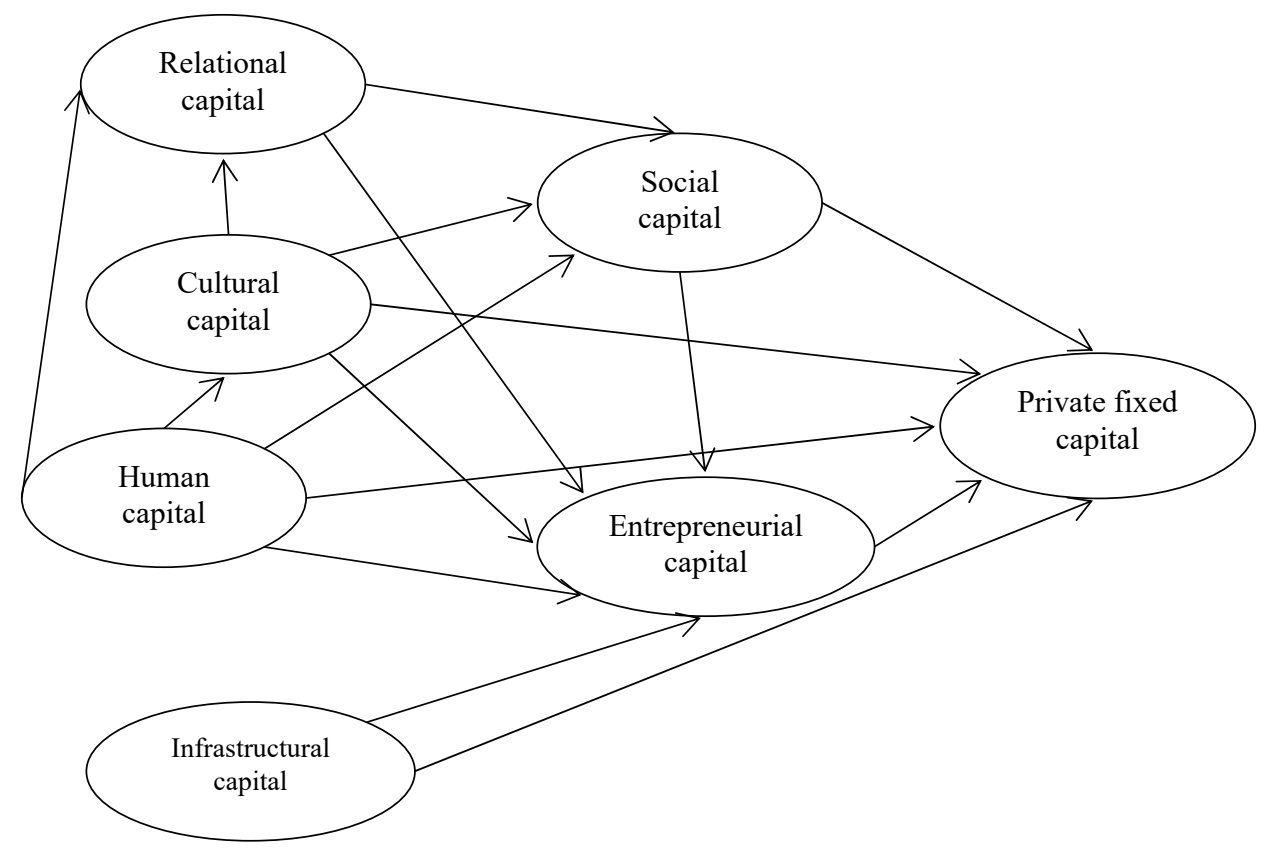

It is important to note that the model is intended to be applied with a confirmative purpose. As Münnich and Hidegkuti (2012) stated regarding the potential uses, it is verified how much the data confirm the currently hypothetical connections of the capital factors.

The PLS path model presented in this part has an outer and an inner model. The inner model refers to the developed latent factors and their relationships, while the outer model consists of the elements (indicators) forming each factor. The "top left" part of the inner model (Figure 3) includes the immaterial factors, while the material factors are found at the bottom.

\footnotetext{
${ }^{5}$ The concept of welfare is interpreted as the synonym of private fixed capital, which is, by definition, an over-simplification, but it may help the interpretation of the objective to be appropriately captured.
} 
In all three examined years, it was based on the relations featured in Figure 3, aiming to construct them. It can be assumed that Cultural, Human, and Relational capital directly shape social capital, and social capital exerts a direct effect on private fixed capital and entrepreneurial milieu. In addition, cultural capital affects relational capital. While in the case of the material capital factors, Infrastructural capital presumably has a significant direct relationship with both entrepreneurial milieu and private fixed capital.

As it is described by Kovács and Bodnár (2017), the reliability of latent variables is often examined using the measure of Cronbach's $\alpha$, relying on the correlations between the manifest (directly observable) variables corresponding to the latent variables. The measure is required to be minimum 0.6 . On the other hand, over the course of the PLS algorithm, the degree of internal consistency is underestimated by Cronbach's alpha, assuming that each variable has identical loading. The measure of composite reliability is used to overcome this problem, which takes account of the different loading values attached to the variables. The measure is required to be over 0.7 . The requirements regarding both measures are fulfilled in the analysis (Table 2).

Table 2 Attributes of forms of capital

\begin{tabular}{lccccccccc}
\hline & \multicolumn{3}{c}{ Cronbach alpha } & \multicolumn{3}{c}{ Composite Reliability } & \multicolumn{4}{c}{$\begin{array}{c}\text { Average Variance } \\
\text { Extracted (AVE) }\end{array}$} \\
\cline { 2 - 11 } latent variable year & 2009 & 2013 & 2017 & 2009 & 2013 & 2017 & 2009 & 2013 & 2017 \\
\hline Human capital & 0.781 & 0.750 & 0.722 & 0.780 & 0.795 & 0.750 & 0.553 & 0.571 & 0.514 \\
Infrastructural capital & 0.773 & 0.730 & 0.847 & 0.854 & 0.832 & 0.898 & 0.601 & 0.556 & 0.688 \\
Relational capital & 0.775 & 0.800 & 0.797 & 0.849 & 0.861 & 0.851 & 0.535 & 0.555 & 0.545 \\
Cultural capital & 0.855 & 0.801 & 0.829 & 0.899 & 0.862 & 0.879 & 0.646 & 0.565 & 0.604 \\
Private fixed capital & 0.853 & 0.873 & 0.806 & 0.892 & 0.907 & 0.863 & 0.627 & 0.664 & 0.563 \\
Social capital & 0.877 & 0.854 & 0.831 & 0.910 & 0.897 & 0.881 & 0.670 & 0.639 & 0.598 \\
Entrepreneurial milieu & 0.705 & 0.760 & 0.820 & 0.807 & 0.850 & 0.884 & 0.521 & 0.561 & 0.608 \\
\hline
\end{tabular}

The analysis of the validity of the latent construction refers to the verification of convergent and discriminant validity. In this case, convergent validity examines whether a set of variables is representative of the same artificial variable. It is indicated by the value of average variance extracted (AVE), which shows for each latent variable the average percentage of retaining the variance of its manifest variables. The requirement towards the AVE value is minimum 0.5 (Henseler et al. 2009).

As established by Kovács and Bodnár (2017), the verification of discriminant validity is examining whether the latent variables discriminate to a sufficient extent. The verification is most commonly conducted based on Fornell-Larcker criterion and cross-loading values. Over the course of analysing the criterion, it is verified whether the AVE value of the latent variables is higher than the square of their correlation by pair with the other latent variables. In the examination of crossloading values, it is verified if the correlation by pair of each manifest variable with its own latent variable is actually higher than with the other ones. 
Kovács and Bodnár (2017) also note that using Monte-Carlo simulation. Henseler et al. (2015) mention two validity verification procedures and do not show the non-compliance of discriminant validity. In their work, they suggested an alternative procedure, the assessment of the so-called HTMT (heterotrait-monotrait) correlation ratio for each latent variable pair. The numerator of the ratio is the average of the correlation coefficients by pair between the manifest variables related to two different latent variables, while its denominator includes the average of the correlation coefficients by pair between the manifest variables related to the same latent variable. According to the Authors (2017), it is sufficient for the values of HTMT indexes to be under 0.9 to assume discriminant validity (See Annex II).

Overall, it can be concluded that the test results of the seven capital factors in the examined three years are obtained in the case of average extracted variance, composite reliability, and Cronbach's a measure as well. Regarding the HTMT index, one value is insufficient in three cases, respectively. They slightly diverge from the required values, thus, based on investigational decision, the analysis was assessed to be completable.

\section{PLS path analysis - developed model}

After testing the latent variables, the question arises whether the direct relationships found in the model are significant. As the significance of the path coefficients can be directly examined while running PLS, the procedure was run by bootstrapping of 5000 subsamples (Table 3 ).

With regard to social capital, it must be noted that due to the specificity of the indicators involved to measure the factor, a higher value is associated with a higher level of underdevelopment.

Table $3 P$ values of the original model, 2009

\begin{tabular}{lcrr}
\hline Path & Path coefficients & T value & P value \\
\hline Human capital -> Relational capital & 0.709 & 17.226 & 0.000 \\
Human capital -> Cultural capital & 0.192 & 2.385 & 0.017 \\
Human capital -> Private fixed capital & -0.015 & 0.147 & 0.883 \\
Human capital -> Social capital & -0.375 & 3.601 & 0.000 \\
Human capital -> Entrepreneurial milieu & 0.251 & 2.087 & 0.037 \\
Infrastructural capital -> Private fixed capital & 0.514 & 6.998 & 0.000 \\
Infrastructural capital -> Entrepreneurial milieu & -0.067 & 0.883 & 0.377 \\
Relational capital -> Social capital & -0.225 & 2.047 & 0.041 \\
Relational capital -> Entrepreneurial milieu & 0.609 & 5.912 & 0.000 \\
Cultural capital -> Relational capital & 0.193 & 3.485 & 0.000 \\
Cultural capital -> Private fixed capital & 0.036 & 0.718 & 0.473 \\
Cultural capital -> Social capital & -0.196 & 2.748 & 0.006 \\
Cultural capital -> Entrepreneurial milieu & 0.047 & 0.641 & 0.522 \\
Social capital -> Private fixed capital & -0.398 & 5.821 & 0.000 \\
Social capital -> Entrepreneurial milieu & -0.076 & 1.278 & 0.201 \\
Entrepreneurial milieu -> Private fixed capital & 0.111 & 1.258 & 0.209 \\
\hline Note: Significant correlion, with $p<0.05$ & & &
\end{tabular}

Note: Significant correlation, with $p<0.05$

It is to be noted that the development of the model required several runs, as despite the fact that a path is not significant in a given relationship, it still can be 
significant if other paths change. Its reverse may also be true. In Table 4, the path between infrastructural capital and private fixed capital is significant, but it eventually was not included in the 2009 model (Table 4.). The $p$ values of the direct relationships of the years 2013 and 2017 are featured in the Annex.

Omitting the non-significant direct paths, in the final model (regarding all three years), six capitals explain the factor of private fixed capital indirectly or directly. These six capital factors include two material capitals (entrepreneurial milieu and infrastructural capital) and four immaterial capital factors (cultural capital, human capital, social capital, and relational capital).

Table 4 P values of the final model, 2009

\begin{tabular}{lccc}
\hline Path & Path coefficients & T value & P value \\
\hline Human capital -> Relational capital & 0.715 & 16.458 & $<0.001$ \\
Human capital -> Cultural capital & 0.199 & 2.264 & 0.024 \\
Human capital -> Social capital & -0.543 & 10.782 & $<0.001$ \\
Infrastructural capital -> Entrepreneurial milieu & 0.363 & 4.358 & $<0.001$ \\
Cultural capital -> Relational capital & 0.195 & 3.235 & 0.001 \\
Cultural capital -> Social capital & -0.233 & 3.316 & 0.001 \\
Social capital -> Private fixed capital & -0.570 & 7.938 & $<0.001$ \\
Social capital -> Entrepreneurial milieu & -0.353 & 4.712 & $<0.001$ \\
Entrepreneurial milieu -> Private fixed capital & 0.308 & 3.827 & $<0.001$ \\
\hline
\end{tabular}

Note: Significant correlation, with $p<0.05$

Source: own creation

Similarly to the logic of the endogenous renewed pyramid model (Lengyel 2017; Lengyel-Szakálné Kanó 2012), each capital was categorised as long-run sources, drivers, or targets (Figure 4-5-6). Long-run sources include cultural, relational and human capital as immaterial elements, as well as infrastructural capital as a material factor. The factors of social capital and entrepreneurial milieu were involved, which was interpreted as a kind of business-entrepreneurial milieu, as drivers in the model. The target is represented by the above-mentioned private fixed capital.

Regarding the year 2009, it can be found (Figure 4) that cultural capital and human capital affect social capital, the former having a weak, while the latter having a medium effect. Social capital directly shapes both entrepreneurial milieu and private fixed capital. Thus, although human capital does not have a direct effect on the target variable, it shapes it through four paths indirectly. It first exerts its effect through social capital, secondly through the relationship of cultural and social capital, thirdly through social capital and entrepreneurial milieu, and finally through the path of cultural capital, social capital, and entrepreneurial milieu. By these indirect paths, human capital shapes private fixed capital with medium strength $((-0.543) *(-0.570)+0.199$ ${ }^{*}(-0.223) *(-0.570)+(-0.543) *(-0.353) * 0.308+0.199 * *(-0.223) *(-0.353)$ * $0.308 \sim 0.400)$.

As for infrastructural capital, it is shown that it has a direct effect on entrepreneurial milieu, thus it shapes private fixed capital indirectly. A slightly weaker than medium relationship $(0.363)$ is found with the factor representing the performance of enterprises, while its indirect effect on private fixed capital $(0.363$ * $0.308=0.112$ ) is rather weak. 


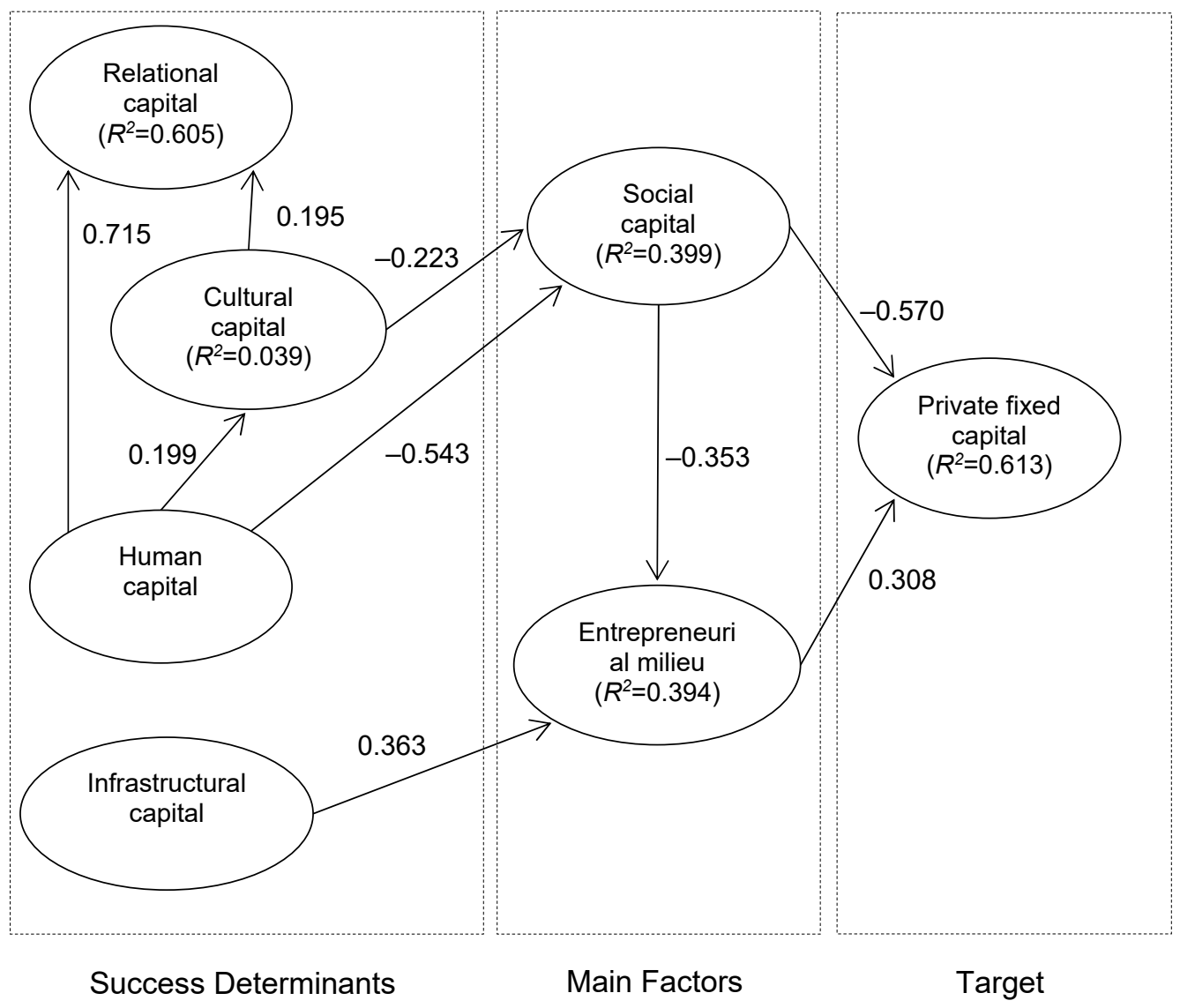

The role of relational capital in the model is interesting as it does not influence any of the capital factors it would be assumed to do so. However, it is shaped by human capital strongly (0.715), while marginally by cultural capital $(0.195)$.

Social capital $(-0.570)$ has the strongest direct effect on private fixed capital, the impact of entrepreneurial milieu $(0.308)$ is much weaker. The variance of the capital representing the target can be explained in over 61 per cent based on the model, i.e., it is influenced in almost 39 per cent by other factors not included in the model.

It was considered to be worth presenting the values of the correlations between each capital factor. Their examination suggests that there is a mediumstrong relationship between the capital factors. The exceptions are the relations between cultural and infrastructural capital, and cultural and human capital, in which cases it is more about the lack of relationship. On the other hand, there is a strong correlation between relational capital and entrepreneurial milieu (0.795), and there is also a strong relationship between relational and human capital $(0.754)$. 
The special character of the datasets forming social capital has already been mentioned; thus, it is clearly shown that there is a positive correlation between each capital (Table 5).

Table 5 Correlations between the forms of capital, 2009

\begin{tabular}{lccrrrrr}
\hline & $\begin{array}{c}\text { Human } \\
\text { capital }\end{array}$ & $\begin{array}{c}\text { Infrastructural } \\
\text { capital }\end{array}$ & $\begin{array}{r}\text { Relational } \\
\text { capital }\end{array}$ & $\begin{array}{c}\text { Cultural } \\
\text { capital }\end{array}$ & $\begin{array}{c}\text { Private } \\
\text { fixed }\end{array}$ & $\begin{array}{r}\text { Social } \\
\text { capital }\end{array}$ & $\begin{array}{c}\text { Entrepreneurial } \\
\text { milieu }\end{array}$ \\
\hline Human capital & 1.000 & & & & & & \\
Infrastructural & 0.675 & 1.000 & & & & & \\
Relational capital & 0.754 & 0.658 & 1.000 & & & & \\
Cultural capital & 0.199 & 0.147 & 0.337 & 1.000 & & & \\
Private fixed capital & 0.647 & 0.736 & 0.669 & 0.292 & 1.000 & & \\
Social capital & -0.589 & -0.538 & -0.560 & -0.340 & -0.739 & 1.000 & \\
Entrepreneurial & 0.719 & 0.553 & 0.795 & 0.307 & 0.621 & -0.548 & 1.000 \\
\hline
\end{tabular}

The size of the direct and indirect effect of each latent variable on private fixed capital was explored. The direct effects correspond with the path coefficients (shown in Figure 4), while all direct and indirect effects are provided by the values of the total effects table (Table 6).

Besides the direct effects of the already mentioned social capital $(-0.570)$ and entrepreneurial milieu (0.308) on private fixed capital, a weak indirect effect is exerted by cultural $(0.158)$ and infrastructural capital $(0.112)$. The indirect effect of human capital (0.400), as previously discussed, is stronger than the previously mentioned ones.

Considering the year of $2013^{6}$, it can be established that the relationships do not show a substantial change. The most important difference compared to the earlier state is that at this time, Infrastructural capital affects private fixed capital directly as well, although this effect is weak (0.283). Therefore, besides the emergence of the above-mentioned path, the same paths are significant as in 2009. Regarding the strength of relationships, only a few significant changes can be found. The direct effect of entrepreneurial milieu on the target variable decreased (2009: 0.308; 2013: 0.173 ), and social capital has a less determinative influence on entrepreneurial milieu (2009: -0.353 ; 2013: -0.212 ). It is also worth mentioning in the case of social capital that its effect on private fixed capital is lower compared to the previous studied period.

Table 6 Values of total effect, 2009

\begin{tabular}{lccrcc}
\hline & $\begin{array}{c}\text { Relational } \\
\text { capital }\end{array}$ & $\begin{array}{c}\text { Cultural } \\
\text { capital }\end{array}$ & $\begin{array}{c}\text { Private fixed } \\
\text { capital }\end{array}$ & Social capital & $\begin{array}{c}\text { Entrepreneurial } \\
\text { milieu }\end{array}$ \\
\hline Human capital & 0.754 & 0.199 & 0.400 & -0.589 & 0.208 \\
Infrastructural capital & & & 0.112 & & 0.363 \\
Cultural capital & 0.195 & & 0.158 & -0.233 & 0.082 \\
Social capital & & & -0.679 & & -0.353 \\
Entrepreneurial milieu & & & 0.308 & & \\
\hline
\end{tabular}

\footnotetext{
${ }^{6}$ Annex 7 features the values related to 2013 and 2017 of the test results of PLS path analysis earlier presented in relation to 2009 .
} 
It is also found that the strength of the already existing relationships increased in four cases, but to a modest, one could say marginal extent in all four cases. The effect of cultural capital on social capital changed minimally, and the same can be said about the effect of human capital on cultural and relational capital, as well as about the relationship of infrastructural capital and entrepreneurial milieu.

As for the entire model, it can be highlighted that the variance of private fixed capital can be explained with the model in over 64 per cent, thus, this value shows some increase (Figure 5).

Figure 5 Interactions of forms of capital explaining private fixed capital, 2013

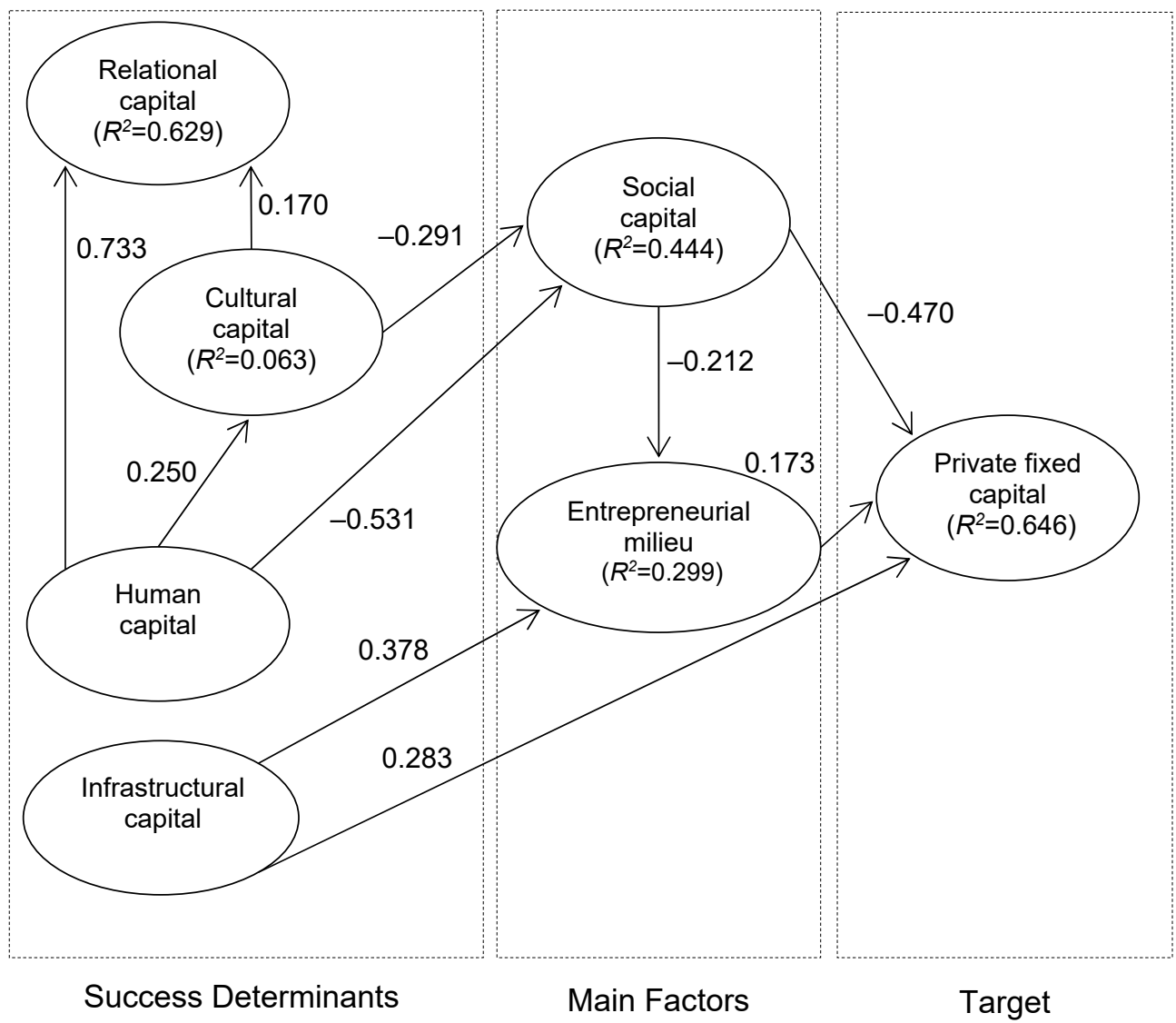

A different picture emerges in 2017 (Figure 6). The third examined situation indicates that four previous paths are discontinued, while three new ones appear. More specifically, in 2017, the relationship between infrastructural capital and entrepreneurial milieu cannot be considered significant, social capital no longer shapes entrepreneurial milieu, human capital does not affect cultural capital, and the effect of cultural capital on social capital also stops. 
On the other hand, at this time, cultural capital directly modifies private fixed capital, although the effect is marginal (0.186). Furthermore, a new path emerges in the case of relational capital, strongly affecting entrepreneurial milieu (0.845).

Here again, there are marginal modifications among the previously and currently existing significant paths regarding the strength of effects. It can also be established that the variance of private fixed capital decreased, it can be explained in 60 per cent with the help of the model.

It can be concluded that in 2017 , first time in the examined time frames, all capital factors influence private fixed capital. The strongest direct effect on the capital defined as the target is exerted by social capital $(-0.365)$, while the strongest indirect effect is exerted by human capital (0.355).

Figure 6 Interactions of forms of capital explaining private fixed capital, 2017

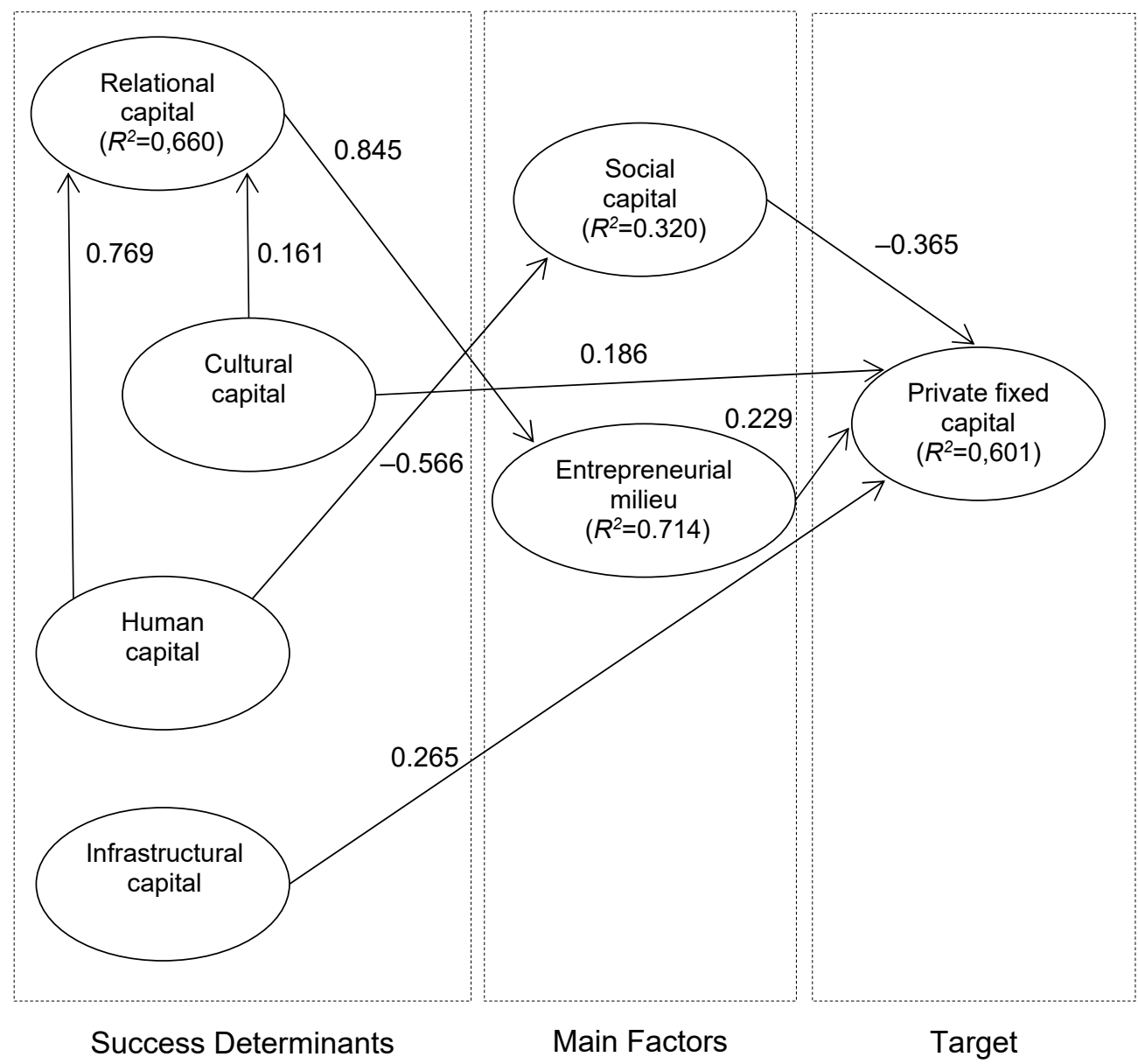

Jóna (2013) and Tóth (2014) investigated the concept of territorial capital, which can be described as a narrower segment of endogenous development. Jóna (2013) analyzes all the Hungarian subregions with the help of a multidimensional 
regression analysis. In the study, territorial capital is the dependent variable which is formed by seven forms of capital. The author states that infrastructural and social capital barely had an effect on territorial capital between 2004 and 2010 . During this period, relational and cultural capitals had the most remarkable impact on territorial capital. These factors are followed by private fixed capital, institutional capital, and human capital. It is a notable remark, especially considering the comparison with the present paper.

The analysis indicates that social capital has a significant impact on the dependent variable in each year. Nevertheless, it is a fact that the effect of this latent variable becomes weaker over time. In 2009, the total effect (-0.679) can be regarded strong, but in 2017, it is only moderate (-0.365) (See Annex III).

Tóth (2014) studies the appearance of territorial capital in Hungary as well. In his analysis, he excludes Budapest and focuses on the territorial attractiveness regarding domestic immigration between 2006 and 2011. He suggests that the chance of higher living standards has a quite strong link to immaterial assets (cultural and human capital).

The strength of human capital in the model has been mentioned earlier and a similar conclusion has been revealed. Nonetheless, in the model, cultural capital does not play a significant role. It has a weak effect (around 0.2) on private fixed capital in each year. According to Jóna's (2013), Tóth's (2014) and this analysis, it can be established that analyses with a similar logic but in various territorial frameworks may lead to quite different results.

\section{Conclusions and future research possibilities}

In the study, the role of endogenous forms of capital was measured in a rural context. The PLS path analysis approach is a novel tool within territorial research, especially if the focus is on rural differences. With the help of the method, the interactions between the various forms of capital were shown, as well as their changes over time. In line with the aim of the analysis, it is believed it may be able to contribute to the academic literature and widen the empirical analysis accomplished with the abovementioned statistical method.

It can be concluded that the role of the capital factors featured in the model is "evident". Regarding the effects of human capital, the negative sign is due to the specificity of the indicators forming it. Thus, all capital factors have a positive effect on private fixed capital.

In the paper, the relationships were studied between capitals through a dynamic approach. The analysis conducted in 2009, 2013 and 2017 indicates that the relationship between the capitals shows temporal differences.

In 2009 and 2013, with one exception, the same paths are significant between the capitals, their strength shows marginal modifications. Both years imply that cultural, human, and infrastructural capitals, considered as long-run factors, shape private fixed capital in an indirect way. These leverage effects emerge through the drivers, i.e., a social capital and entrepreneurial milieu.

Compared to the above-mentioned years, 2017 shows a completely different system of relations. At this time, four paths are discontinued, but three other ones emerge instead. Thus, for instance, the path between infrastructural capital and entrepreneurial milieu is not significant. On the other hand, the infrastructural factor directly shapes private fixed capital. Human capital has a direct effect on social and 
relational capitals, but not on cultural capital. In addition, another new path is formed between relational capital and entrepreneurial milieu, the former factor having a strong effect $(0.845)$ on the latter. Consequently, over this year, all capital factors influence private fixed capital.

It is interesting, but definitely not positive, that human capital does not affect private fixed capital directly in any of the years. Although the finding may require further research, it implies that the rural presence of human capital is rather marginal.

As a limitation, the territorial framework of the analysis must be emphasised. The countryside is a unique territory differing from urban settlements, the special characteristics of which are determined by the settlements, economy, and society surrounding it. This environment provides a special context to the analysis; thus, the findings of the paper are only valid within these given conditions.

In the future, it may be worth expanding the time interval of investigation. A longer process could reveal deeper connections, which could help understand the existing interrelations better or make it easier to predict future development paths. Moreover, it must be mentioned once again that natural capital could not be quantified. It is obvious that this form of capital belongs to the countryside, and this failure may also lead to new research directions in the future.

\section{References}

AEIDL [European Association for Information on Local Development] (1999) Territorial competitiveness. Creating a territorial development strategy in light of the LEADER experience. Part 1. LEADER European Observatory AEIDL, Bruxelles, http://www.esponontheroad.eu/dane/web_espon_library_files/698/zl_competiti vity.pdf Downloaded: 12 June 2019

Affuso, A., Camagni, R. (2010) Territorial Capital and Province Performance in the Latin Arch: An Econometric Approach. Politecnico di Milano. http://www.grupposervizioambiente.it/aisre/pendrive2010/pendrive/Paper/affus o1.pdf Downloaded: 12 November 2014

Amin, A. (1999) An Institutionalist Perspective on Regional Economic Development. International Journal of Urban and Regional Research, 23 (2), 365-378.

Atkinson, R. (2013) Territorial Capital, Attractiveness and the Place-based Approach: the Potential Implications for Territorial Development. In Pálné Kovács, I., Scott, J., Gál, Z. (Eds.), Territorial Cohesion in Europe. For the 70th Anniversary of the Transdanubian Research Institute. IRS CERS HAS, Pécs, 297-308.

Benko, G. (1997) A regionális fejlődés útjai: globálistól a lokálisig. Tér és Társadalom, 11 (2), 1-16.

Bodnár G. (2011) What is rural?: Some Possible Methods to Define Rural Areas. In: Ferencz, Á. (Ed.), Erdei Ferenc VI. Tudományos Konferencia, Kecskeméti Főiskola Kertészeti Főiskolai Kar, Kecskemét, Vol. 1, 235-239.

Braithwaite, K. (2009) Building on What You Have Got - A Guide to Optimising Assets. Carnegie UK Trust, Dunfermline, UK.

Brasili, C., Saguatti, A., Benni, F., Marchese, A., Gandolfo, D. (2012) The Impact of the Economic Crisis on the Territorial Capital of Italian Regions. 52 ${ }^{\text {nd }}$ European Regional Science Congress. 21-25 August. Bratislava. http://wwwsre.wu.ac.at/ersa/ersaconfs/ersa12/e120821aFinal00646.pdf 
Camagni, R. (2008) Regional competitiveness: towards a concept of territorial capital. In Capello, R., Camagni, R., Chizzolini, B., Fratesi, U. (Eds.), Modelling regional scenarios for the enlarged Europe. Springer-Verlag, Berlin, 33-47.

Camagni, R., Caragliu, A., Perucca, G. (2011) Territorial Capital. Relational and Human Capital. Draft version. Politecnico di Milano. Milano. http://www.grupposervizioambiente.it/aisre_sito/doc/papers/Camagni_Caragliu Perucca.pdf Downloaded: 2 July 2015

Capello, R. (2007) Regional Economics. Routledge, Oxon.

Capello, R. (2011) Location, Regional Growth and Local Development Theories. Aestimum, 58 (1), 1-25.

Capello, R. (2012) Regional Economics: Theoretical Achievements and Challenges. Timisoara Journal of Economics, 18 (5), 313-335.

Capello, R., Nijkamp, P. (2011) Regional growth and development theories revisited. In Stimson, R., Stough, R. R., Nijkamp. P. (Eds.), Endogenous Regional Development. Perspectives, Measurement and Empirical Investigation. Edward Elgar, Cheltenham, UK - Northampton, MA, USA, 301-324.

Capello R., Perucca G. (2013) Do Eastern European Regions Move Towards an Endogenous Growth Pattern? A Diachronic Perspective of Regional Success Factors. GRINCOH Working Paper Series, Paper No. 1.15

Chant, S., Mcllvaine, C. (2009) Geographies of Development in the 21st Century. An Introduction to the Global South. Edward Elgar, Cheltenham, UKNorthampton, MA, USA.

Csatári B. (2001) A vidék földrajzi kérdései. In Dormány G., Kovács F., Péti M., Rakonczai J. (Eds.), A földrajz eredményei az új évezred küszöbén. SZTE TTK Természeti Földrajzi és Geoinformatikai Tanszék, Szeged, 1-9. http://geography.hu/mfk2001/cikkek/Csatari.pdf Downloaded: 8 October 2010

Dinya L. (2013) „Zöld” prioritások érvényesítése a megyei szintű területfejlesztési stratégiákban. Journal of Central European Green Innovation, 1 (1), 21-33.

EC [European Comission] (2017) Competitiveness in low-income and low-growth regions. The lagging regions report. Commission Staff Working Document. Brussels.

Egri, Z., Tánczos T. (2015) Spatial Layers and Spatial Structure in Central and Eastern Europe. Regional Statistics, 5 (2), 34-61.

Enyedi Gy. (1998) Sikeres régiók, In Tények könyve: régiók. Greger-Delacroix, 409-411.

ETC [ETC Foundation - Compas] (2007) Learning Endogenous Development Building on Bio-cultural Diversity. ETC Foundation - Compas, Bourton on Dunsmore, Rugby, Warwickshire, UK.

Henseler J., Ringle C. M., Sarstedt M. (2015) A New Criterion for Assessing Discriminant Validity in Variance-based Structural Equation Modeling. Journal of the Academy of Marketing Science, 43 (1), 115-135.

Henseler J., Ringle C. M., Sinkovics R. R. (2009) The use of partial least squares path modeling in international marketing. New Challenges to International Marketing (Advances in International Marketing, Vol. 20), 277-319.

Hoff, K., Stiglitz, J. E. (2001) Modern Economic Theory and Development. In Meier, G. M., Stiglitz, J. E. (Eds.), Frontiers of Development Economics. The Future in Perspective. World Bank - Oxford University Press, Oxford-Washington, 389- 459. 
Jóna Gy. (2013) A területi töke kistérségi jellegzetességei. Doctoral Dissertation. Szent István Egyetem Enyedi György Regionális Tudományok Doktori Iskola, Gödöllö.

Kitson, M., Martin, R., Tyler, P. (2004) Regional Competitiveness: An Elusive yet Key Concept? Regional Studies, 38 (9), 991-999.

Kovács P. - Bodnár G. (2017) Examining the Factors of Endogenous Development in Hungarian Rural Areas by Means of PLS Path Analysis. Regional Statistics, 7 (1), 90-114.

Lengyel I. (2012a) Regionális növekedés, fejlődés, területi tőke és versenyképesség. In Bajmócy Z., Lengyel I., Málovics Gy. (Eds.), Regionális innovációs képesség, versenyképesség és fenntarthatóság. JATEPress, Szeged, 151-174.

Lengyel I. (2012b) A hazai területfejlesztés zsákutcái: a triális Magyarország. In Rechnitzer J., Rácz Sz. (Eds.), Dialógus a regionális tudományról. Széchenyi István Egyetem Regionális- és Gazdaságtudományi Doktori Iskola, Magyar Regionális Tudományi Társaság, Győr, 140-150.

Lengyel I. (2017) Competitive and uncompetitive regions in transition economies: the case of the Visegrad post-socialist countries. In Huggins, R., Thompson, P. (Eds.), Handbook of Regions and Competitiveness. Contemporary Theories and Perspectives on Economic Development. Edward Elgar, Cheltenham, UK - Northampton, MA, USA, 398-415.

Lengyel I., Szakálné Kanó I. (2012) Competitiveness of Hungarian Urban Microregions: Localization Agglomeration Economies and Regional Competitiveness Function. Regional Statistics, 2 (2), 27-44.

Lewis, W. A. (1988) The Roots of Development Theory. In Chenery H., Srinivasan, T. N. (Eds.), Handbook of Development Economics. (Vol. I.) Elsevier, Amsterdam, 27-37.

Milone, P., Ventura, F., Berti, G. \& Brunori, G. (2010) Some Notes on the Identification of Rural Webs. In Milone, P., Ventura, F. (Eds.), Networking the Rural. Royal Van Gorcum, Assen, The Netherlands, 30-48.

Münnich Á., Hidegkuti I. (2012) Strukturális egyenletek modelljei: oksági viszonyok és komplex elméletek vizsgálata pszichológiai kutatásokban. Alkalmazott Pszichológia, 15 (1), 77-102.

Pociūtè-Sereikienè, G., Kriaučiūnas, E., Ubarevičienè, R. (2014) Peripheralisation trends in rural territories: the case of Lithuania. Studies in Agricultural Economics, $116(3), 122-130$.

Rechnitzer J. (2016) A területi tőke a városfejlődésben. A Győr-kód. Dialóg Campus Kiadó, Budapest-Pécs.

Robbins, L. (1968) The Theory of Economic Development int he History of Economic Thought. London-Basingstoke, Macmillan.

Sen, A. (1988) The Concept of Development. In Chenery H., Srinivasan, T. N. (Eds.), Handbook of Development Economics. (Vol. I.) Elsevier, Amsterdam, 9-26.

Smętkowski M. (2018) The role of exogenous and endogenous factors in the growth of regions in Central and Eastern Europe: the metropolitan/non-metropolitan divide in the pre- and post-crisis era. European Planning Studies, 26 (2), 256-278.

Stimson, R., Stough, R. R., Nijkamp. P. (2011) Endogenous Regional Development. In Stimson, R., Stough, R. R., Nijkamp. P. (Eds.), Endogenous Regional Development. Perspectives, Measurement and Empirical Investigation. Edward Elgar, Cheltenham, UK - Northampton, MA, USA, 1-19. 
Stimson, R., Stough, R. R. \& Salazar, M. (2009) Leadership and Institutions in Regional Endogenous Development. Edward Elgar, Cheltenham, UK Northampton, MA, USA.

Szentes T. (2011) Fejlődés-gazdaságtan. Akadémiai Kiadó, Budapest.

TelR (2021): TelR database, www.teir.hu and http://uj.lechnerkozpont.hu/en/oldal/teir

Todaro, M. P., Smith, S. C. (2009): Economic Development. (11 ${ }^{\text {th }}$ ed) Addison-Wesley, Boston.

Tödtling, F. (2009) Endogenous Regional Development. In Kitchin, R., Thrift, N. (Eds.), International Encyclopedia of Human Geography, Elsevier, Oxford, 208-213.

Tóth B. I. (2013) A területi tőke szerepe a regionális- és városfejlődésben Esettanulmány a magyar középvárosok példáján. Doktori értekezés. Nyugatmagyarországi Egyetem Széchenyi István Gazdálkodás- és Szervezéstudományok Doktori Iskola, Sopron.

Tóth. B. I. (2014) A hazai kistérségek vonzerejének és területi tőkéjének néhány összefüggése. Területi Statisztika. 54 (1), 3-18.

Tubadji, A., Nijkamp. P. (2015) Cultural impact on regional development: application of a PLS-PM model to Greece. The Annals of Regional Science, 54 (3), 680-720.

Vázquez-Barquero, A., Rodríguez-Cohard, J. C. (2016) Endogenous Development and Institutions: Challenges for Local Development Initiatives. Environment and Planning C: Government and Policy, 34 (6), 1135-1153.

Vermeire, B., Gellynck, X., De Steur, H., Viaene, J. (2008) The role of social capital assets in reconciling endogenous and exogenous drivers of rural renewal. 8th European IFSA Symposium, 6 - 10 July 2008, Clermont-Ferrand, France, http://ifsa.boku.ac.at/cms/fileadmin/Proceeding2008/2008_WS6_06_Vermeire. pdf Downloaded: 21 July 2014

\section{Annex}

Annex I Indicators of each capital, 2009

\begin{tabular}{ll}
\hline Forms of capital & \multicolumn{1}{c}{ Indicators } \\
\hline & \multicolumn{1}{c}{ Material capital } \\
\hline \multirow{3}{*}{ Private fixed capital } & Total domestic income (Ft) per capita \\
& Total income of full-time jobs (Ft) per capita \\
& Total floor area $\left(\mathrm{m}^{2}\right)$ of built properties in the same year per 1000 inhabitants \\
& Number of passenger cars by residence of operator per 1000 inhabitants \\
\hline & Balance sheet total (total assets) (1000 Ft) per registered entrepreneurship \\
& Number of registered limited partnerships per 1000 inhabitants \\
Entrepreneurial & Number of registered limited companies per 1000 inhabitants \\
milieu & Number of registered agricultural cooperatives per 1000 inhabitants \\
& Number of registered limited liability companies per 1000 inhabitants \\
& Number of registered joint venture per 1000 inhabitants - GFO'11 \\
\hline \multirow{3}{*}{ Infrastructural } & Amount of sewage disposal in public collecting system per 1000 inhabitants \\
capital & (1000 m3) \\
& Amount of sewage disposal in public collecting system from households per 1000 \\
& inhabitants (1000 m3) \\
& Internet subscriptions per 1000 inhabitants \\
& Number of telephone lines (including ISDN lines) per 1000 inhabitants
\end{tabular}


Total number of registered long-term (180 days) job-seekers per 1000 inhabitants Number of constant replacement migration per 1000 inhabitants

Social capital

Number of full-time pedagogues in primary education per 1000 inhabitants (including specific education)

Number of juvenile offenders (year 14-17) within registered offenders per 1000 inhabitants

Number of registered offenders (by location) per 1000 inhabitants

Number of full-time students in tertiary education per 1000 inhabitants (by location)

Human capital Number of lecturers in tertiary education per 1000 inhabitants (by location)

Number of registered companies per 100000 inhabitants in the section of professional, scientific and technical activities

Number of creative cultural collectivities per 1000 inhabitants

Number of members of creative cultural collectivities per 1000 inhabitants

Cultural capital

Number of cultural events per 1000 inhabitants

Number of participants of cultural events per 1000 inhabitants

Number of participants of regular forms of culture per 1000 inhabitants

Number of registered partnerships per 1000 inhabitants in the section of accommodation and food service activities

Number of registered companies per 1000 inhabitants in the section of accommodation and food service activities

Relational capital Number of registered partnerships per 1000 inhabitants in the section of information and communication

Number of registered companies per 1000 inhabitants in the section of information and communication

Number of registered non-profit organisations per 1000 inhabitants

Note: Some indicators have different names in 2013 and in 2017. These negligible differences have no influence on the dynamic analysis.

\section{Annex II Values of the HTMT correlation ratio}

\begin{tabular}{lccc}
\hline Pairs of latent variables & & HTMT values & \\
& 2009 & 2013 & 2017 \\
\hline Infrastructural capital - Human capital & 0.677 & 0.696 & 0.653 \\
Relational capital - Human capital & 0.608 & 0.657 & 0.616 \\
Relational capital - Infrastructural capital & 0.806 & $0.950^{*}$ & 0.777 \\
Cultural capital - Human capital & 0.243 & 0.230 & 0.360 \\
Cultural capital - Infrastructural capital & 0.233 & 0.367 & 0.204 \\
Cultural capital - Relational capital & 0.435 & 0.449 & 0.403 \\
Private fixed capital - Human capital & 0.521 & 0.620 & 0.613 \\
Private fixed capital - Infrastructural capital & $0.913^{\star}$ & 0.875 & 0.766 \\
Private fixed capital - Relational capital & 0.708 & 0.759 & 0.728 \\
Private fixed capital - Cultural capital & 0.321 & 0.337 & 0.331 \\
Social capital - Human capital & 0.489 & 0.564 & 0.509 \\
Social capital - Infrastructural capital & 0.629 & 0.834 & 0.823 \\
Social capital - Relational capital & 0.596 & 0.639 & 0.488 \\
Social capital - Cultural capital & 0.383 & 0.499 & 0.283 \\
Social capital - Private fixed capital & 0.802 & 0.835 & 0.786 \\
Entrepreneurial milieu - Human capital & 0.613 & 0.599 & 0.597 \\
Entrepreneurial milieu - Infrastructural capital & 0.653 & 0.619 & 0.556 \\
Entrepreneurial milieu - Relational capital & 0.862 & 0.893 & $0.905^{*}$ \\
Entrepreneurial milieu - Cultural capital & 0.388 & 0.368 & 0.213 \\
Entrepreneurial milieu - Private fixed capital & 0.670 & 0.606 & 0.612 \\
Entrepreneurial milieu - Social capital & 0.609 & 0.528 & 0.470 \\
\hline Note: * Over the required results & & & \\
\hline
\end{tabular}

Note: *: Over the required results 
Annex III: Test values of PLS Path Analysis

Values of the year 2013

$P$ values of the final model, 2013

\begin{tabular}{lccc}
\hline Path & Path coefficients & T value & P value \\
\hline Human capital -> Relational capital & 0.733 & 16.487 & 0.000 \\
Human capital -> Cultural capital & 0.250 & 3.168 & 0.002 \\
Human capital -> Social capital & -0.531 & 10.502 & 0.000 \\
Infrastructural capital -> Private fixed capital & 0.283 & 2.857 & 0.004 \\
Infrastructural capital -> Entrepreneurial milieu & 0.378 & 3.943 & 0.000 \\
Cultural capital -> Relational capital & 0.170 & 2.770 & 0.006 \\
Cultural capital -> Social capital & -0.291 & 4.118 & 0.000 \\
Social capital -> Private fixed capital & -0.470 & 5.779 & 0.000 \\
Social capital -> Entrepreneurial milieu & -0.212 & 2.619 & 0.009 \\
Entrepreneurial milieu -> Private fixed capital & 0.173 & 2.945 & 0.003 \\
\hline
\end{tabular}

Note: Significant correlation, with $p<0.05$

Correlations between the forms of capital, 2013

\begin{tabular}{lccccccc}
\hline & $\begin{array}{c}\text { Human } \\
\text { capital }\end{array}$ & $\begin{array}{c}\text { Infrastructural } \\
\text { capital }\end{array}$ & $\begin{array}{c}\text { Relational } \\
\text { capital }\end{array}$ & $\begin{array}{c}\text { Cultural } \\
\text { capital }\end{array}$ & $\begin{array}{c}\text { Private } \\
\text { fixed } \\
\text { capital }\end{array}$ & $\begin{array}{c}\text { Social } \\
\text { capital }\end{array}$ & $\begin{array}{c}\text { Entrepreneurial } \\
\text { milieu }\end{array}$ \\
\hline Human capital & 1.000 & & & & & & \\
Infrastructural capital & 0.730 & 1.000 & & & & & \\
Relational capital & 0.776 & 0.685 & 1.000 & & & & \\
Cultural capital & 0.250 & 0.215 & 0.354 & 1.000 & & & \\
Private fixed capital & 0.670 & 0.702 & 0.667 & 0.288 & 1.000 & & \\
Social capital & -0.604 & -0.698 & -0.572 & -0.424 & -0.750 & 1.000 & \\
Entrepreneurial milieu & 0.698 & 0.526 & 0.821 & 0.273 & 0.546 & -0.475 & 1.000 \\
\hline
\end{tabular}

Values of total effect, 2013

\begin{tabular}{lccccc}
\hline & $\begin{array}{c}\text { Relational } \\
\text { capital }\end{array}$ & $\begin{array}{c}\text { Cultural } \\
\text { capital }\end{array}$ & $\begin{array}{c}\text { Private fixed } \\
\text { capital }\end{array}$ & Social capital & $\begin{array}{c}\text { Entrepreneurial } \\
\text { milieu }\end{array}$ \\
\hline Human capital & 0.776 & 0.250 & 0.306 & -0.604 & 0.128 \\
Infrastructural capital & & & 0.348 & & 0.378 \\
Cultural capital & 0.170 & & 0.148 & -0.291 & 0.062 \\
Social capital & & & -0.507 & & -0.212 \\
Entrepreneurial milieu & & & 0.173 & & \\
\hline
\end{tabular}

Values of the year 2017

$P$ values of the final model, 2017

\begin{tabular}{lccc}
\hline Path & Path coefficients & T value & P value \\
\hline Human capital -> Relational capital & 0.769 & 17.864 & 0.000 \\
Human capital -> Social capital & -0.566 & 13.130 & 0.000 \\
Infrastructural capital -> Private fixed capital & 0.265 & 2.530 & 0.011 \\
Relational capital -> Entrepreneurial milieu & 0.845 & 23.094 & 0.000 \\
Cultural capital -> Relational capital & 0.161 & 2.258 & 0.024 \\
Cultural capital -> Private fixed capital & 0.186 & 2.434 & 0.015 \\
Social capital -> Private fixed capital & -0.365 & 4.289 & 0.000 \\
Entrepreneurial milieu -> Private fixed capital & 0.229 & 3.769 & 0.000 \\
\hline
\end{tabular}

Note: Significant correlation, with $p<0.05$ 
Correlations between the forms of capital, 2017

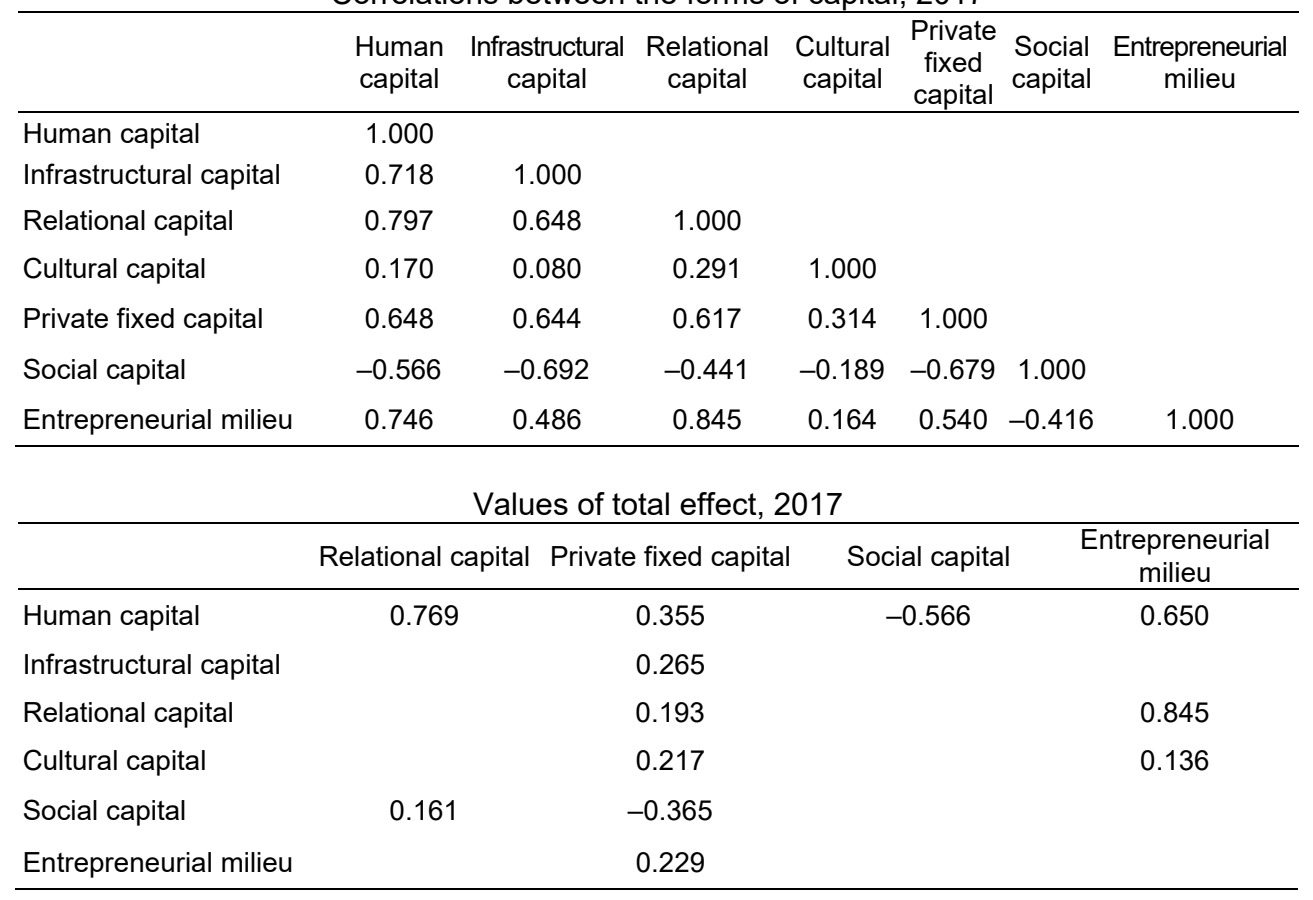

